\title{
Development of Humanistic Statistics Learning Devices Based one Inquiry and Mind Mapping Models
}

\author{
Santika Lya Diah Pramesti ${ }^{1}$, Salafudin ${ }^{2}$ \\ ${ }^{1,2}$ IAIN Pekalongan \\ ${ }^{1}$ Correspondence Address; Santi123@gmail.com
}

\begin{abstract}
The purpose of this research are: (1) to determine the characteristic of humanistic statistics learning, (2) to obtain a humanistic statistics learning tools based on valid, practical, and effective inquiry and mind mapping learning model. The research method uses 4D Thiagarajan which has been modified to 3D, namely: define, design, and develop. Implementation of the development and humanistic statistics learning tool trials using Inquiry and Mind Mapping learning model show that learning tools used in statistical learning activities were practical and effective. The trial shows an increase of students' statistical problem-solving ability using humanistic learning based on Inquiry and Mind Mapping learning model. The improvement of statistical problemsolving on Inquiry learning model is better than humanistic statistics learning using Mind Mapping learning model.
\end{abstract}

Keywords: Humanistic Statistics; Inquiry; Learning; Mind Mapping.

\section{INTRODUCTION}

Learning is a process that occurs in human by thinking, feeling, and moving to understand every reality they wanted to produce a behavior, knowledge, or technology or anything in the form of human work and initiative. In a learning also needs to be supported by the existence of a theory and learning in general, learning theory is grouped into four groups, namely: (1) behavioristic learning theory (2) cognitivist learning theory (3) constructivist learning theory (4) humanistic learning theory (Yasin, 2016). One of learning theory is humanistic learning theory, learning is considered successful if the learner or student understand their environment and themselves, student in the learning process have to try so that they are able to achieve selfactualization as well as possible. This learning theory attempt to understand learning habits from the doers' perspective, not from the observers' perspective (Uno, 2006).

The description above shows that how important it is to describe and learn about humanistic learning theory and its implication on learning in the middle of education failure in Indonesia which is more concerned in cognitive aspects as the biggest reference in measuring education quality in Indonesia. In humanistic learning theory, learning process must be upstream and lead to human beings. This research focuses on statistics subject so that we are expected to know about the characteristic of humanistic statistics learning. One of learning models that provides space for students to apply learning experience gained in everyday life, all together with using a humanist approach is Inquiry and Mind Mapping model. Inquiry learning model motivates students to active in learning, while Mind Mapping learning model encourages students to learn about how to map statistical concepts into real forms using imagination and understanding to the matter which being taught. The implication of humanistic statistics learning by this Inquiry and Mind Mapping learning model will produce valid, practical, and effective learning tools. 
Several researches have been done in the development of learning tools for humanistic statistics by Inquiry Model (Amidi, Waluya, \& Hindarto, 2014; Krisdiana, 2016; Nisa, 2017; Putri \& Widiyatmoko, 2013; Uswatun \& Rohaeti, 2015; Widiyatmoko, 2013). Based on previous research, the renewal in this research is on the development of learning tools to determine the characteristic of humanistic statistics learning and obtain learning tools for humanistic statistics based on valid, practical, and effective Inquiry and Mind Mapping model.

\section{THE RESEARCH METHODS}

This research is a type of development research. The development that was carried out was the development on Humanistic Statistics Learning Tools Based on Inquiry and Mind Mapping Models. Developed learning tools are: (1) Syllabus, (2) Lecture Program Units, (3) Problem-solving Ability Test. The development of learning tools in this research refers to the 4-D Thiagarajan development model, et al. However, this research only took 3D, namely Define, Design, and Develop refers to previous research (Firdaus, Widodo, \& Azizah, 2014; Netra et al., 2013; Rosida \& Rochmawati, 2013; Sumarno \& Wustqa, 2014). The purpose of Define phase is to establish and define the development requirements. The defining phase includes five main steps, namely front-end analysis, learner analysis, task analysis, concept analysis, specifying instructional objectives. The purpose of Design phase is to prepare a prototype learning model. The initial design is learning tool design along with the instruments to be developed. The learning tools which will be developed is Syllabus, Lecture Plans, and Problem-solving Ability Test. The designed research instruments includes learning tool validation sheets, student activity observation sheets and teachers' ability to manage learning, student motivation questionnaire, and student and lecturer response questionnaire sheets. The design results of this development tools is the draft I of the development of learning tools. The purpose of Develop phase is to modify a prototype of learning tools so as to produce a learning tools. This development phase consists of validation of learning tools and trials. Validation of learning tools is done by competent specialists and practitioners. The specialist assessment aims to obtain suggestions, critics that are used as an input for revising learning tools (initial draft/draft I) so the draft II is produced which can be categorized well and suitable for field trials. The stages in this validation generally include 1) validation of learning tool contents, whether it is in accordance with the matter and the objectives to be measured, 2) validation in terms of language, whether the learning tools use good and properly Bahasa (Indonesian Language) or whether the sentences on learning tools are not creating double meanings.

The results of the tool developments on draft II were tested in the trial class/experimental class. The purpose of this tool trial is to obtain an input in the form of the record of all responses, reactions, comments from students, lecturers, and peer obsevations to revise or complete draft II. The subjects of this research were the students from Study Program PAI which consist of 6 parallel classes. Two classes were taken as the samples, namely as experimental class. Sampling is carried using a sample random sampling system because members of the population are considered homogene. (Sugiyono, 2009). 
The research design of learning tool trials used true-experimental design with pretest posttest control group design. The paradigm in this model trial research can be seen in the following Table.

\begin{tabular}{lccc}
\multicolumn{4}{c}{ Table 1. The Design of Learning Tool Trial } \\
\hline Class & Pretest & Treatment & Posttest \\
Experiment 1 & T1 & X & T2 \\
\hline Experiment 2 & T1 & Y & T2 \\
\hline
\end{tabular}

In this design, there were two groups, each of which was chosen randomly. The first and the second group were experimental class. The first group (X) was taught the humanistic statistics learning using Inquiry model, the second group (Y) was taught the humanistic statistics learning using Mind Mapping model. The value of previous test results of the two groups were taken from the mid-term examination (UTS) as the first pretest (T1) to determine the state of the initial abilities of the students between the first and the second experimental class. After receiving treatments, the two of the trial classes did a posttest which was a problemsolving ability test on comparative analysis matter (T2).

This research was carried out in IAIN Pekalongan. Subject trials were students at statistics class in Study Program PAI IAIN Pekalongan academic year 2015/2016. The implementation of learning tool trials in the classroom enclose two observers from peers, namely a statistics lecturer and a Tarbiyah lecturer. Each observer had the duty to observe students' activity during learning process in the classroom. This research used two class samples which was chosen randomly by researcher, namely the trial class of problem-solving ability question test and the class as experimental class.

The types of data collected were qualitative and quantitative data. The qualitative data were obtained based on observations, documentations, interviews, and tool validations. The quantitative data were obtained based on the result of nuanced problem-solving ability test which students did. The instruments used on data collection were: problem-solving ability test, validation sheet of learning tools, observation sheets, response questionnaire sheet.

The data analysis technique used in this research were validity data analysis on learning tools, homogeneity test, question analysis on problem-solving ability test, data analysis on practicality learning tools, and data analysis on the effectiveness of humanistic statistics learning using Inquiry and mind mapping learning model.

\section{THE RESULT OF THE RESEARCH AND THE DISCUSSION}

In the define phase, the assumption is obtained that: (1) the achievement of statistical learning is still low for IAIN Pekalongan students, this is can be seen from the number of students who take SP for statistics course, (2) some statistics lecturers have not developed learning tools and proponent independently, in accordance with the applicable standard process and have not met valid, practical, and effective criteria, (3) the available learning tools have not led to humanistic and innovative learning activities that can improve students' problem-solving ability, (4) low activeness and motivation of the students in statistical learning, because statistics is considered as scourge and is not interesting course. 
Based on theoretical studies in the define phase, in this phase learning tools are designed in accordance to humanistic statistics learning based on Inquiry and Mind Mapping model. The designed learning tools are Syllabus, Lecture Program Unit, and Problem-solving Ability Test. Problem-solving ability test (TKPM) in this research is designed with a humanistic nuance. Questions are made regarding to statistical contents and the level of students' statistical abilities. This problem-solving ability test (TKPM) with humanistic nuance is for measuring the ability/level of students' problem-solving on the matter that has been taught.

Whereas in this develop phase, learning tool validation and revision is carried out, then the results of the learning tool revisions that had been declared valid by validator is used for learning tool trials in the classroom. To find out whether the learning tools are valid or not, learning tools are validated by validator (specialist and practitioners) is needed. The validator that did the validation of learning tools that developed in this research consist of 4 people including 3 specialists from IAIN Pekalongan lecturers and 1 mathematics lecturer from UNIKAL Pekalongan. The suggestions from the specialists are used as a basis for improving learning tools.

After the learning tools were validated and declared feasible to be tested, learning tool trials were tested in Inquiry and Mind Mapping experiment classes. Learning tool trials on the field aims to find out the practical and effectiveness of learning tools. Learning tool trials were carried out in experimental classes, namely class A and B Study Program PAI. During this trial process, data collection process was carried out including observation data of the learning process and students' activities. After the trial process, humanistic nuance TKPM was conducted to measure problem-solving ability of the students in the tool trial class. Before learning tool trials were carried out, homogeneity test was needed between class A and B. the purpose of homogeneity test is to find out whether experimental class have the same initial abilities. The data that was used to find out about initial abilities of the students were taken from the previous daily test scores, namely on the correlation analysis matter.

The data that was obtained then processed using independent sampels test (in SPSS) with a significance level of 0.05 and the complete results can be seen in Appendix D.2. Based on the results of the data process it was found that the number of research subjects in experimental class A was 37 students and 50 students in experimental class B. The result of SPSS shows that significance value on Levene's Test for Equality of Variances column in Independent Sample Test $=0.068=6.8 \%>5 \%$ so $\mathrm{H}_{0}$ is accepted or the variance of two variables are same. In other words, the control class and experimental class are homogene or have the same initial abilities.

Learning tools said to be practical after tested in experimental class if obtained the results: (1) a positive students' responses, (2) lecturers give at least a good response, and (3) the ability of the lecturer to manage the learning at least have a good score. The data of students' response that obtained from questionnaires were analyzed by determining the number of respondents who gave a positive and negative response for category asked in the questionnaires. From the results of students' response questionnaire, it was then percentage and obtained that $75.20 \%$ of Mind Mapping class and $78.06 \%$ of Inquiry class gave a positive response, in other words 
students gave a positive response because more than $75 \%$ students gave a positive response on humanistic statistics learning based on Inquiry and Mind Mapping model.

Lecturers' response questionnaire includes the opinion of the lecturer on the component of learning tools in assisting learning activities, the assessment of the lecturer on learning tools and the lecturers' response on the feasibility of the development of learning tools. The results of lecturers' response questionnaire on learning tools are then analyzed. The average result of lecturers' response on learning tools that using Inquiry model is 4.17 and on learning tools that using Mind Mapping model is 4.08. So, the lecturers' response on learning tools is in a good category. To determine the lecturers' abilities on managing the learning, there must be an observation of the lecturers' abilities. The observation was done during learning process by 2 observers from colleagues. The total average of lecturers' abilities to manage humanistic statistics learning using Inquiry learning model is in a high category, so the lecturers' abilities to manage the learning is said to be good. The total average of lecturers' abilities to manage humanistic statistics learning using Mind Mapping learning model is in a high category, so the lecturers' abilities to manage the learning is said to be good.

The results of humanistic nuance TKPM data were first tested using normality test. This normality test was used to determine whether the results of problem-solving ability data were normal distribution or not. In this research, normality test is done by SPSS using KolmogorovSmirnov with significance level of $1 \%$. Based on normality test, it was obtained that significance value of experimental class A using Inquiry learning model $=0.03=3 \%>1 \%$ so $\mathrm{H}_{0}$ was accepted, it means that the results of humanistic nuance TKPM in experimental class A were normal distribution. The results of humanistic nuance TKPM for experimental class B obtained significance value of $0.059=5.9 \%>1 \%$ so Ho was accepted. It means that the result of humanistic nuance TKPM in experimental class B were normal distribution.

This average difference test was used to compare the average of students' problemsolving ability on humanistic statistics learning between using Inquiry and Mind Mapping learning model. This average difference test uses right-sided T-test. Before the data were tested using T-formula, data normality and homogene were tested first. For normality test, the results of humanistic nuance TKPM data have been tested in the previous section, so normal distribution was obtained. The results of two variants similarity test (homogeneity) uses SPSS. Based on independent samples test output Table in SPSS, it was obtained that significance value $=0.008=0.8 \%$, this means significance level is $<5 \%$. Thus null hypothesis $\left(\mathrm{H}_{0}\right)$ is rejected, or $\mathrm{H}_{1}$ is accepted, it means that the variance of problem-solving ability of the two experimental class is different.

Calculations using T-formula on excel, obtained T-calculated value of 3.39. With significance level of 5\%, obtained T-table value of 1.67. Because T-calculated value (3.39) > T-table value (1.67) so $\mathrm{H}_{1}$ is accepted. Therefore, it can be concluded that the average of students' problem-solving ability on humanistic statistics learning based on Inquiry learning model are less than the average of students' problem-solving ability on humanistic statistics learning based on Mind Mapping learning model. 
Besides the average difference test is used to compare the Inquiry and Mind Mapping learning model, this test is also used to test before and after using humanistic statistics learning model and using Inquiry and Mind Mapping learning model. The hypothesis is as follows.

T-paired test on Inquiry learning model

$H_{0}: \mu_{1} \leq \mu_{2}$ (the average of students' problem-solving ability after taught using humanistic statistics learning based on Inquiry learning model is less than or equal to the average of students' problem-solving ability before taught using humanistic statistics learning based on Inquiry learning model)

$H_{1}: \mu_{1}>\mu_{2}$ (the average of students' problem-solving ability after taught using humanistic statistics learning based on Inquiry learning model is more than the average of students' problem-solving ability before taught using humanistic statistics learning based on Inquiry learning model)

Calculation shows the value of T-calculated $=4.80$. With significance level of $5 \%$, obtained $\mathrm{T}$-table $=1.67$. Because $\mathrm{t}_{\text {calculated }}>\mathrm{t}_{0,5-0,05}$ so $\mathrm{H}_{1}$ is accepted. Thus, it can be concluded that the average of students' problem-solving ability after taught using humanistic statistics learning based on Inquiry learning model is better than before.

T-paired test on Mind Mapping learning model

$H_{0}: \mu_{1} \leq \mu_{2}$ (the average of students' problem-solving ability after taught using humanistic statistics learning based on Mind Mapping learning model is less than or equal to the average of students' problem-solving ability before taught using humanistic statistics learning based on Mind Mapping learning model)

$H_{1}: \mu_{1}>\mu_{2}$ (the average of students' problem-solving ability after taught using humanistic statistics learning based on Mind Mapping learning model is more than the average of students' problem-solving ability before taught using humanistic statistics learning based on Mind Mapping learning model)

Calculation shows the value of T-calculated $=4.80$. With significance level of $5 \%$, obtained T-table $=1.67$. Because $t_{\text {calculated }}>t_{0,5-0,05}$ so $\mathrm{H}_{1}$ is accepted. Thus, it can be concluded that the average of students' problem-solving ability after taught using humanistic statistics learning based on Mind Mapping learning model is better than before.

The problem in this research is how to develop humanistic statistics learning tools based on valid, practical, and effective Inquiry and Mind Mapping learning model. The developed learning tools are categorized as valid if have gone through validation process by specialist and practitioner with average score of each tools in a good or very good category. For humanistic nuance TKPM, it is determined first to fulfill the content validity, then trial is conducted to fulfill the specified requirements, namely reliable, difficulty level of balance, and minimal distinguishing power. The development of learning tools have gone through the process according to developing tool procedures that have been determined in this research, namely Thiagarajan modification model, et al. Based on validation results, learning tools are declared as valid, but revision is still needed. The revision results of learning tools are no longer 
requested for validation to the validator, it was immediately made into draft 2 of learning tools which will be subsequently used on learning tool trials in the class.

Learning tools is said to be practical if after being tested in experimental class, they obtained results: (1) students' response are positive, (2) lecturers' response on learning tools are positive, and (3) lecturers' ability on managing the learning are good.

The comparison of students' problem-solving ability in humanistic statistics learning class based on Inquiry and Mind Mapping learning model using average difference test. Based on analysis results, it can be concluded that the average score of problem-solving ability test on control class is not same with the average of experimental class. The results of data processing using average difference test showed that tool trial class have an average value of problemsolving ability that was not same, problem-solving ability in Inquiry learning model class is better than Mind Mapping learning model in experimental class. It is because learning in experimental class involves habitual activities using realistic humanistic learning, close to students, as well as habitual exercises with humanistic nuance questions. Other than that, students become active in learning, for example when there are discussion activity or group to make props. Realistic statistics learning in Indonesia makes students feel happy so that it raises students' motivation and learning become more meaningful (Johar: 9).

The development of humanistic statistics learning tools to improve problem-solving ability is very likely to occur because learning can really happened. The development of humanistic statistics learning tools in experimental class both using Inquiry learning model or Mind Mapping learning model créate learning process and transfer more optimal knowledge. Student learning motivation to achieve completeness and to solve challenging humanistic nuance questions are an important factor in this research to support the purpose of this research in improving students' problem-solving ability. Activities also have an effect on students' problem-solving ability because when student activities appear physically, mentally, and socially, so physical, mental, and social abilitities will also develop so that it will improve their problem-solving ability. Humanistic nuance question exercises on humanistic statistics learning makes students have higher problem-solving ability, in accordance with Suherman (2003: 55). So activities and motivations are two things that are related to each other and strengthen each other to obtain an optimal problem-solving ability.

The results of the influence of student activity analysis on realistic statistics learning in Indonesia on students' problem-solving ability stated that there is a linear relationship. It shows that the higher student activities, the higher problem-solving ability will be achieved. Statistical learning with humanistic approach has characteristics for statistical reinventing activities. So, the efforts to increase student activities on humanistic statistics learning process using Inquiry and Mind Mapping learning model must always be conducted so that the desire to improve students' problem-solving ability can be realized.

The results of T-test showed an improvement of students' problem-solving ability on humanistic statistics learning using Inquiry learning model or using Mind Mapping learning model than before. The improvement of students' problem-solving ability on humanistic statistics learning using Inquiry learning model is more increased than Mind Mapping learning 
model. Humanistic statistics learning makes students become active in learning and students become accustomed to humanistic nuance questions. The exercises of humanistic nuance questions train students' problem-solving ability gradually on solving the question and calculation accuracy.

Humanistic statistics learning trials with assessment of humanistic nuance shows the results in the form of: 1) students' problem-solving ability on humanistic statistics learning using Inquiry and Mind Mapping learning model increased, 2) students' problem-solving ability using Inquiry learning model are higher than students with humanistic statistics learning using Mind Mapping learning model, 3) there is a positive influence on student activity and student motivation on students' problem-solving ability, and 4) the improvement of students' problem-solving ability on humanistic statistics learning with assessment of humanistic nuance. From those four things, it means that humanistic statistics learning trials based on Inquiry and Mind Mapping learning model have an effective humanistic statistics learning results.

\section{CONCLUSION AND SUGGESTION}

Research on the development of humanistic statistics learning tools using Inquiry and Mind Mapping learning model produces learning tools namely: Syllabus, Lecture Program Unit (SAP), Student Books, and Statistical Problem-solving Ability Test with valid Humanistic Nuance. Implementation of the development and humanistic statistics learning tool trials using Inquiry and Mind Mapping learning model show that learning tools used in statistical learning activities were practical and effective. The trial shows an increase of students' statistical problem-solving ability using humanistic learning based on Inquiry and Mind Mapping learning model. The improvement of statistical problem-solving using Inquiry learning model is better than humanistic statistics learning using Mind Mapping learning model.

Based on the conclusion of this research, some suggestions can be put forward for further research, it is expected to be able to investigate the problem with a wider range for the development of science in the world of research, namely in the next research should try to use other learning models to produce other learning tools, or can use Inquiry and Mind Mapping learning model to develop learning model using other learning theories.

\section{REFERENCES}

Amidi, A., Waluya, S. B., \& Hindarto, N. (2014). Pembelajaran Matematika Konstruktivistik Berbasis Humanistik Berbantuan E-Learning Pada Materi Segitiga Kelas VII. Jurnal Matematika Kreatif-Inovatif, 5(2), 121-132.

Firdaus, Z., Widodo, W., \& Azizah, U. (2014). Pengembangan Perangkat Pembelajaran IPA Terpadu Berorientasi Pendekatan SAVI (Somatic, Auditory, Visual, Intellectual) pada Tema Demam Berdarah untuk SMP Kelas VIII. Jurnal Pendidikan Sains E-Pensa, 2(1), 60-67.

Krisdiana, I. (2016). Pengembangan Perangkat Pembelajaran pada Matakuliah Statistika Dasar dengan Metode Problem Based Learning. Jurnal Edukasi Matematika dan Sains, 4(1), 6165. 
Netra, D., Sd, M. I., Semester, K., Pokok, M., Semesta, D. A. N. A., Yuliawati, F., Suprihatiningrum, J. (2013). Pengembangan Modul Pembelajaran Sains Berbasis Integrasi Islam-Sains untuk Peserta Didik Difabel Netra MI/SD Kelas 5 Semester 2 Materi Pokok Bumi dan Alam Semesta. Jurnal Pendidikan IPA Indonesia, 2(2), 169-177.

Nisa, R. M. (2017). Kreativitas dalam Psikologi Humanistik dan Implikasinya dalam Pendidikan. HIKMAH, 6(2), 259-280.

Putri, B. K., \& Widiyatmoko, A. (2013). Pengembangan LKS IPA Terpadu Berbasis Inkuiri Tema Darah di SMP N 2 Tengaran. Jurnal Pendidikan IPA Indonesia, 2(2), 102-106.

Sumarno, S., \& Wustqa, D. U. (2014). Pengembangan Perangkat Pembelajaran pada Materi Pokok Kalkulus SMA Kelas XI Semester 2. Jurnal Riset Pendidikan Matematika, 1(2), 257-267.

Uno, H. B. (2006). Orientasi Baru Dalam Psikologi Perkembangan. Jakarta: Bumi Aksara.

Uswatun, D. A., \& Rohaeti, E. (2015). Perangkat Pembelajaran IPA Berbasis Inkuiri untuk Meningkatkan Critical Thinking Skills dan Scientific Attitude Siswa. Jurnal Inovasi Pendidikan IPA, 1(1), 138-152.

Widiyatmoko, A. (2013). Pengembangan Perangkat Pembelajaran IPA Terpadu Berkarakter Menggunakan Pendekatan Humanistik Berbantu Alat Peraga Murah. Jurnal Pendidikan IPA Indonesia, 2(1), 76-82.

Yasin, M. (2016). Teori Humanistik dalam Pembelajaran. Jurnal An-Nur, 3(2), 46-57. 